ARTICLE

DOI: $10.1038 / s 41467-017-02095-x$

\title{
Geochemical and mineralogical evidence that Rodinian assembly was unique
}

\author{
Chao Liu', Andrew H. Knoll ${ }^{2} \&$ Robert M. Hazen ${ }^{1}$
}

The mineralogy and geochemistry associated with Rodinian assembly ( 1.3-0.9 Ga) are significantly different from those of other supercontinents. Compared to other supercontinents, relatively more $\mathrm{Nb}$-bearing minerals, $\mathrm{Y}$-bearing minerals, and zircons formed during Rodinian assembly, with corresponding enrichments of $\mathrm{Nb}, \mathrm{Y}$, and $\mathrm{Zr}$ concentrations in igneous rocks. By contrast, minerals bearing many other elements (e.g., Ni, Co, Au, Se, and platinum group elements) are significantly less abundant, without corresponding depletion of $\mathrm{Ni}$ and $\mathrm{Co}$ concentrations in igneous rocks. Here we suggest that the $\mathrm{Nb}, \mathrm{Y}$, and $\mathrm{Zr}$ enrichments in igneous rocks and relatively more occurrences of corresponding $\mathrm{Nb}$-bearing minerals, Y-bearing minerals, and zircons result from significant non-arc magmatism during the mid-Proterozoic, while fewer occurrences of many other minerals suggest enhanced erosion of Rodinian volcanic arcs and orogens. The prolonged, extrovert assembly of Rodinia from thickened mid-Proterozoic continental crust via two-sided subduction can account for both the prevalence of non-arc magmatism and the enhanced erosion.

\footnotetext{
${ }^{1}$ Geophysical Laboratory, Carnegie Institution for Science, Washington, DC 20015, USA. ${ }^{2}$ Department of Earth and Planetary Sciences, Harvard University, Cambridge, MA 02138, USA. Correspondence and requests for materials should be addressed to C.L. (email: cliu@carnegiescience.edu)
} 
S upercontinents have assembled and disperzed repeatedly since the late Archean Eon, recorded most conspicuously by the age frequency distribution of detrital zircons ${ }^{1}$. Episodes of supercontinent amalgamation share a number of tectonic and geochemical features ${ }^{2}$; however, increasing evidence suggests that no two supercontinents formed in quite the same manner ${ }^{3,4,5}$. In particular, it has been hypothesized that the supercontinent Rodinia differs distinctly from other supercontinents ${ }^{3}$; Rodinia was assembled through a series of accretionary and collisional events between 1.3 and 0.9 billion years ago $^{6}$; endured through the late stages of Earth's middle age ${ }^{7}$; and broke apart in association with pronounced perturbations to the carbon cycle, global glaciations $^{8}$, and the rise of complex multicellular life ${ }^{9}$. Similar to those of other supercontinents, Rodinian assembly (RA) is marked by a peak in the abundance of detrital zircons with contemporary ages, archiving an integrated result of crustal generation and preservation ${ }^{3,10}$ or punctuated crustal growth ${ }^{11,12}$. Previous studies proposed that Rodinia stands out from other supercontinents in many aspects, such as enhanced anorogenic magmatism, deficiency in continental margins and collisional belts, and dearth in ore deposits and minerals of precious metals, $\mathrm{Hg}$, and other elements ${ }^{7,13-17}$. Many of these proposed aspects, however, are based on regional or outdated geologic and geochemical databases with limited data ${ }^{15,18,19}$. Recently, rapidly expanding global databases of geochemistry, mineralogy, and stratigraphy have begun to facilitate studies of Earth as a system, with emphasis on our planet's evolution through time $e^{20-22}$. In this study, we compile and analyze existing global databases of minerals (data from rruff.info/ima) and igneous geochemistry (data from earthchem.org) through time to test the extent to which Rodinia is geochemically and mineralogically distinct from other supercontinents, and to explore possible reasons underlying observed differences.

Our results indicate that niobium $(\mathrm{Nb})$, yttrium $(\mathrm{Y})$, and zirconium $(\mathrm{Zr})$ concentrations in igneous rocks formed during RA are statistically higher, coupled with more abundances of $\mathrm{Nb}$ bearing and Y-bearing minerals, but many other minerals are less abundant during RA than during assembly of other supercontinents. Such anomalies can be explained by prevalence of non-arc magmatism and enhanced erosion during RA.

\section{Results}

Mineral data. From rruff.info/ima, we compiled 108,857 agelocality records of high-temperature (high-T, i.e., igneous, metamorphic, and hydrothermal) minerals for which ages are well constrained from radiometric dating of corresponding magmatic, metamorphic, or hydrothermal events. Spatially, these minerals are distributed globally (Supplementary information; Supplementary Fig. 1). Temporally, despite a preservational bias toward deposits of the Phanerozoic Eon, the high-T minerals exhibit ages more commonly associated with supercontinent assembly (Fig. 1), similar to detrital zircons ${ }^{23,24}$. This similarity, however, breaks down during RA; the abundance of detrital zircons exhibit one of the strongest peaks observed throughout Earth history, but occurrences of high-T minerals in total are much less pronounced (Fig. 1). Analysis of the high-T mineral data based on mineral chemistry reveals that only a few minerals, including $\mathrm{Nb}$-bearing and Y-bearing minerals, are relatively more abundant than zircons during RA, and that most high-T minerals, especially minerals bearing selenium $(\mathrm{Se})$, gold $(\mathrm{Au})$, nickel $(\mathrm{Ni})$, cobalt (Co), and platinum group elements (PGE), are significantly less abundant at the same time (Fig. 1).

Geochemical data. We compiled whole-rock chemical analyses of dated igneous rocks from http://www.earthchem.org/portal, including concentration data on 129,161 samples for $\mathrm{Zr}, 105,045$ for $\mathrm{Nb}, 121,373$ for $\mathrm{Y}, 77,835$ for $\mathrm{Co}$, and 82,611 for $\mathrm{Ni}$-all are associated with $\mathrm{SiO}_{2}$ content (wt\%) and modern geographic
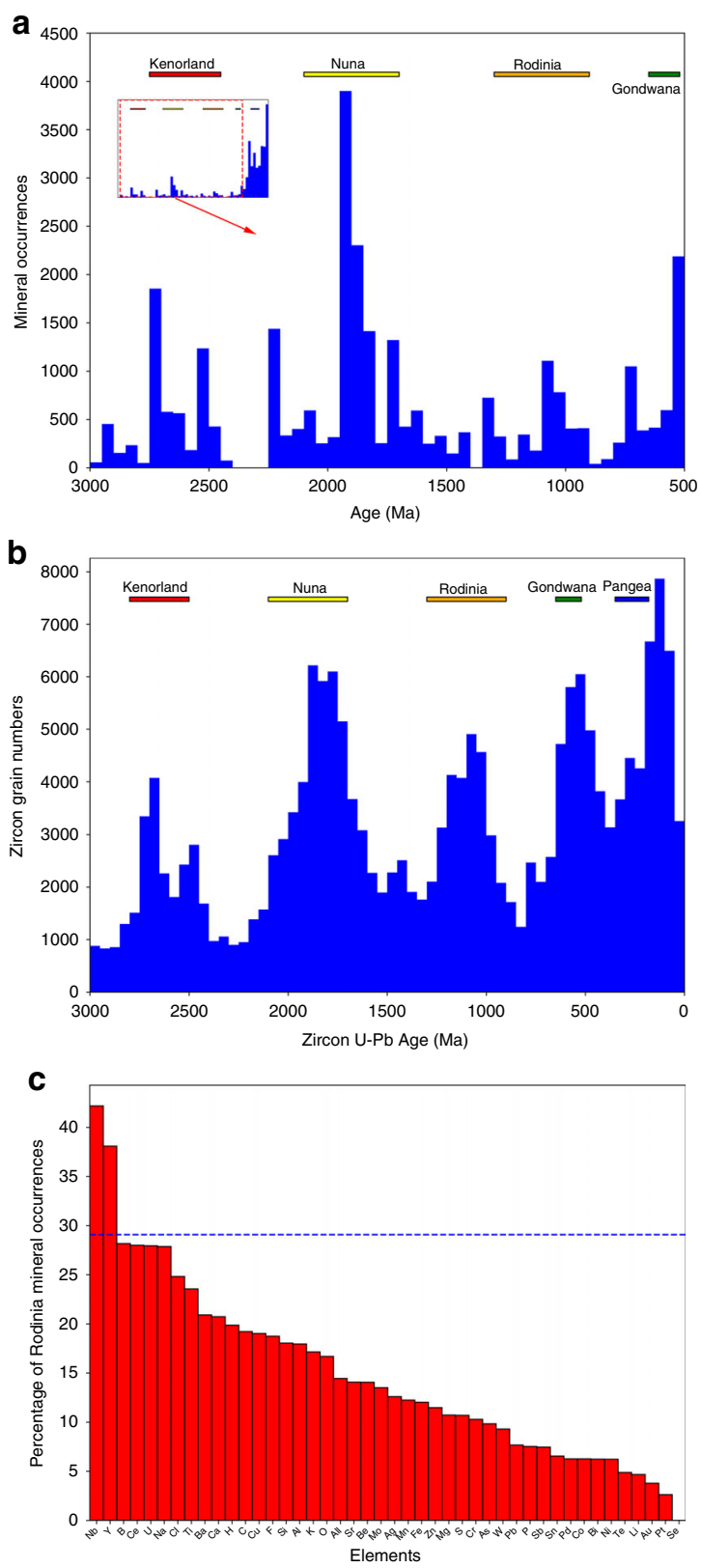

Fig. 1 Temporal distribution of global high-T minerals and detrital zircons. Igneous, metamorphic, and hydrothermal minerals (a) and detrital zircons (b) through the last $3.0 \mathrm{Ga}$, with a bin size of $50 \mathrm{Ma}$. Mineral occurrence is defined in the Methods section. Detrital zircon distribution data is based on ref. ${ }^{24}$. In spite of the significant preservation bias toward the present, high$T$ minerals are generally enriched during supercontinental assemblies, similar to detrital zircons. During Rodinian assembly, high-T minerals are relatively less abundant compared to other supercontinents Panel a displays 3000-500 Ma; inset displays 3000-0 Ma. c A survey based on mineral chemistry showing relative abundances of minerals containing different elements. $Y$-axis is defined as the percentage of entry numbers of specific minerals occurring during RA relative to total entry numbers of those minerals occurring during assemblies of all pre-Pangia supercontinents (dashed blue lines: the percentage of detrital zircon). Except for $\mathrm{Nb}$-bearing and $\mathrm{Y}$-bearing minerals, most minerals are relatively depleted compared to detrital zircon during Rodinia assembly 

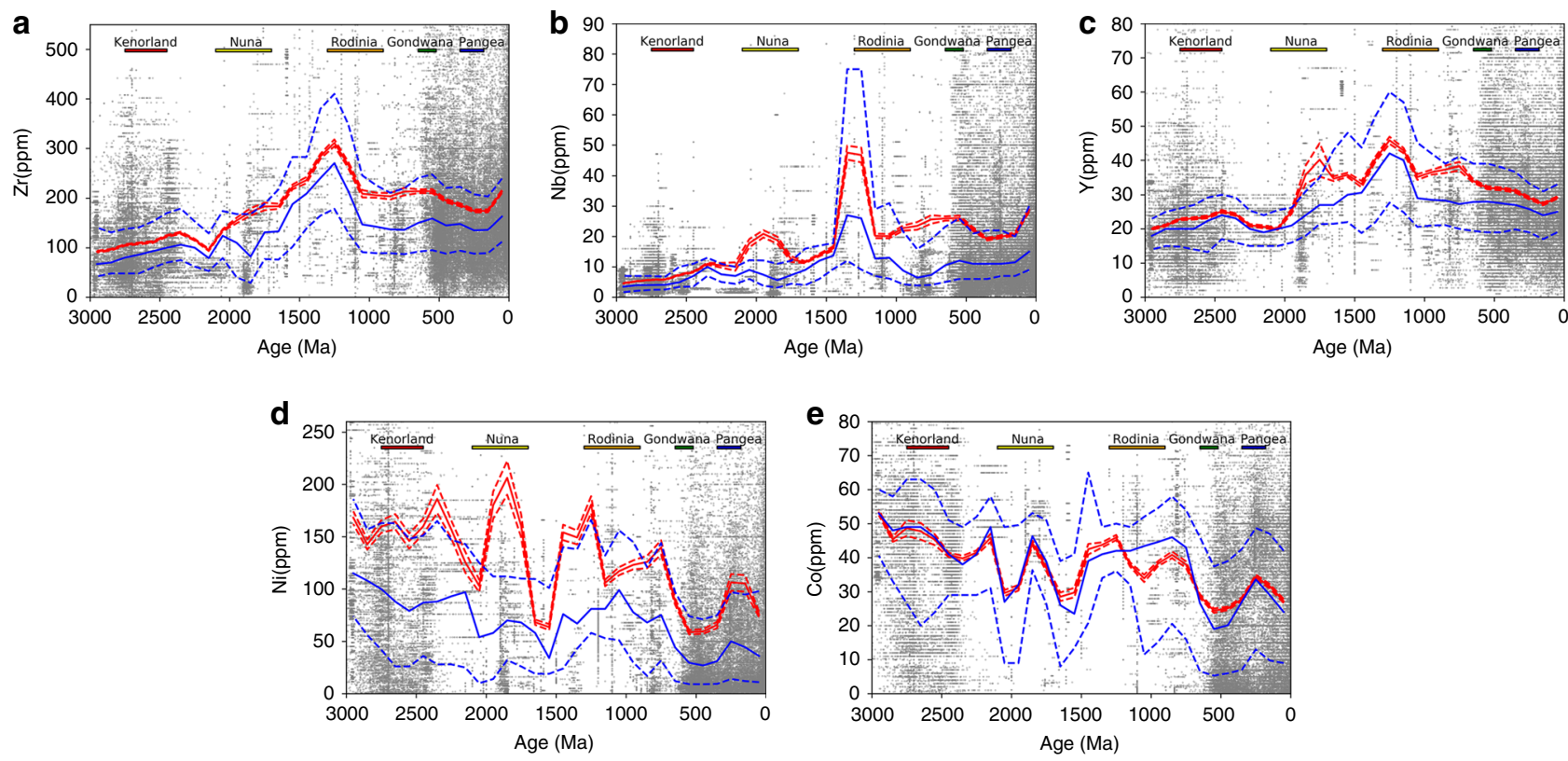

Fig. 2 Trace element concentration. (a, Zr; b, Nb; c, Y; d, Ni; and e, Co) in global igneous rocks through the last $3.0 \mathrm{Ga}$. $\mathrm{Zr}$, Nb, and $\mathrm{Y}$ exhibit the highest values during and immediately before Rodinian assembly, while Ni and Co show no depletions at the same time. The gray filled circles are data resampled from Earthchem with bootstrap resampling. Moving averages and medians of samples within $\pm 100 \mathrm{Ma}$ bin size are calculated for each $100 \mathrm{Ma}$. Red solid line: average; Red dashed lines: 95\% confidence interval of the moving average; Blue solid line: median; Blue dashed lines: the lower (25\%) and upper (75\%) quantiles

Table 1 Results of two-sample Welch's $t$-tests of $\mathrm{Zr}$, Nb, and $\mathrm{Y}$ concentrations between igneous rocks formed during Rodinian assembly and those formed during assemblies of other supercontinents

\begin{tabular}{|c|c|c|c|c|c|c|}
\hline & t-statistic & $p$-value & t-statistic & $p$-value & t-statistic & $p$-value \\
\hline \multicolumn{7}{|l|}{$\mathrm{Zr}$} \\
\hline Rodinia-Nuna & 24.63 & 1.10E-128 & 25.9 & $1.51 \mathrm{E}-137$ & 5.15 & $3.60 E-07$ \\
\hline Rodinia-Gondwana & 2.12 & 0.03 & 7.38 & $3.02 \mathrm{E}-13$ & 2.42 & 0.02 \\
\hline $\begin{array}{l}\text { Rodinia-Pangea } \\
\mathrm{Nb}\end{array}$ & 26.47 & $1.67 E-149$ & 23.16 & $1.86 \mathrm{E}-113$ & 6.81 & 1.77E-11 \\
\hline Rodinia-Nuna & 14.36 & $3.37 \mathrm{E}-46$ & 8.03 & $1.51 \mathrm{E}-15$ & 4.16 & $3.51 \mathrm{E}-05$ \\
\hline Rodinia-Gondwana & 4.33 & $1.52 \mathrm{E}-05$ & -0.13 & 0.88 & 3.88 & 0.0001 \\
\hline $\begin{array}{l}\text { Rodinia-Pangea } \\
Y\end{array}$ & 15.24 & $7.11 \mathrm{E}-52$ & 2.05 & 0.04 & 1.7 & 0.09 \\
\hline Rodinia-Kenorland & 44.02 & 0 & 40.3 & $5.25 \mathrm{E}-304$ & 23.38 & $1.91 E-96$ \\
\hline Rodinia-Nuna & 19.59 & $1.76 E-83$ & 24.49 & $1.57 \mathrm{E}-123$ & 6.99 & $5.24 \mathrm{E}-12$ \\
\hline Rodinia-Gondwana & 13.35 & $2.59 \mathrm{E}-40$ & 10.62 & $5.03 \mathrm{E}-25$ & 9.83 & $8.69 \mathrm{E}-22$ \\
\hline
\end{tabular}

coordinates. Similar to our mineral data, the extracted geochemical data are globally distributed (Supplementary Fig. 1). During RA, multiple statistics of $\mathrm{Nb}, \mathrm{Y}$, and $\mathrm{Zr}$ concentrations in igneous rocks exhibit the highest values in the last $3.0 \mathrm{Ga}$ (Fig. 2), significantly higher than the values during assembly of any other supercontinent (Table 1). Such geochemical enrichments are statistically significant in both mafic and felsic igneous rocks (Table 1), consistent with previous reports of anomalously high $\mathrm{Zr}$ in Laurentian granitoids ${ }^{18}$ and igneous samples from a smaller, older-version Earthchem database ${ }^{19}$. Unlike $\mathrm{Nb}, \mathrm{Y}$, and $\mathrm{Zr}$, neither enrichments nor depletions are observed for $\mathrm{Ni}$ and $\mathrm{Co}$ concentrations in igneous rocks formed during RA (Fig. 2).

\section{Discussion}

Compared to other supercontinental assemblies, the enrichments of $\mathrm{Nb}, \mathrm{Y}$, and $\mathrm{Zr}$ in igneous rocks and more abundant $\mathrm{Nb}$ bearing, Y-bearing minerals, and detrital zircons strongly suggest distinctive tectonics during $\mathrm{RA}$, leading to unique patterns of magmatism and mineralization. For both mafic and felsic igneous rocks, tectonic discrimination ${ }^{25,26}$ based on the immobile trace elements (Fig. 3) implies that geochemical signatures of "within- 

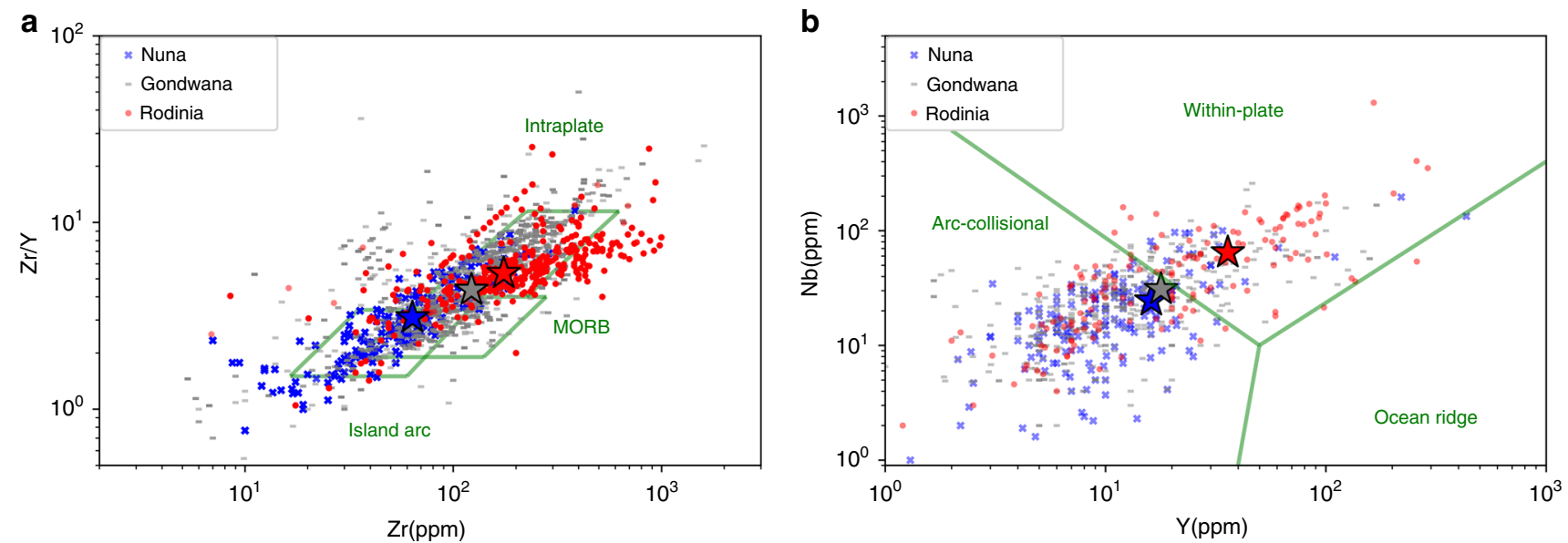

Fig. 3 Tectonic discrimination diagrams. Discrimination diagrams ${ }^{25,26}$ for mafic (a) and felsic (b) rocks formed during assemblies of Nuna (blue, $x$ ), Rodinia (red filled circle), and Gondwana (gray, -) based on concentrations of immobile trace elements. Average values for each supercontinent are plotted as filled stars. "Within-plate/Intraplate" geochemical signatures are dominant for igneous rocks formed during Rodinia assembly, whereas arc-collisional magmatism is relatively more significant for Nuna and Gondwana

plate" magmatism prevail during RA, whereas island arc and collisional magmatism is more, or at least equally, significant during the assembly of other supercontinents (e.g., Nuna, Gondwana). Unlike "within-plate" magmatic rocks normally discovered in intraplate settings, these rocks formed during RA are associated with not only intracontinental rifting ${ }^{27,28}$, but also back-arc settings ${ }^{29}$, and zones of orogenic distension/exhumation during episodic collisional hiatus ${ }^{30-32}$, as long as the tectonic setting is extensional. Such widespread extensional magmatism can be attributed to enhanced asthenosphere-lithosphere interactions $^{27,30,33,34}$, possibly involving a warmer mantle ${ }^{35}$ and/or a thicker continental crust ${ }^{36}$ than at present. It has been speculated that there was a large-scale mantle thermal anomaly ${ }^{35,37}$, possibly due to thermal blanketing and/or heat down-welling of the mantle beneath the long-lived supercontinent Nuna ${ }^{38,39}$. Alternatively, it has been proposed that continental lithosphere was strong enough to be thickened ${ }^{36}$ and to support the emplacement of large plutons into the crust, yet the underlying mantle was still warm enough to result in widespread melting of the lower thickened continental crust ${ }^{7,13,40}$.

Many types of magmatic rocks that were formed during RA, including massif anorthosites ${ }^{41,42}$, A-type granitoids ${ }^{18,43-45}$, and NYF (Nb, Y, and F enriched)-type pegmatites ${ }^{31,46-48}$, are enriched in $\mathrm{Zr}, \mathrm{Nb}$, and $\mathrm{Y}$ relative to arc magmatic rocks ${ }^{18,34,47}$. In arc magmas, these elements are scavenged by interaction with depleted mantle peridotite during subduction ${ }^{49,50}$, while this interaction was mitigated during enhanced asthenosphere-lithosphere interaction ${ }^{30,33}$ or even circumvented during the melting of continental crust ${ }^{40}$, due to a warmer mantle ${ }^{35}$ and/or a thickened continental crust ${ }^{36}$ during RA. Of all the non-arc magmatic rocks formed during RA, NYF-type pegmatites are the most enriched in $\mathrm{Nb}$ and $\mathrm{Y}$, together with fluorine (F). The enrichment of $\mathrm{Nb}$ and $\mathrm{Y}$ is amplified by the strong partitioning of $\mathrm{Nb}$ and $\mathrm{Y}$ into F-rich fluids and melts ${ }^{51-54}$, and $\mathrm{F}$ has been proposed to be sourced from decomposing F-rich biotite and amphibole during crustal anatexis $31,55,56$. As a result, NYFtype pegmatites bear a plethora of rare $\mathrm{Nb}$-bearing and $\mathrm{Y}$-bearing minerals, consistent with the observed $\mathrm{Nb}$ and $\mathrm{Y}$ mineral enrichment during RA.

Unlike the coupled mineral and geochemical enrichments of $\mathrm{Nb}, \mathrm{Y}$, and $\mathrm{Zr}$ during $\mathrm{RA}$, the significant depletions in the abundances of many other minerals (e.g., Se, Au, Ni, Co, and PGE minerals) are not accompanied by any corresponding elemental depletion in igneous rocks (Fig. 2). Rather, diminished mineralization is consistent with a previously reported dearth of ore deposits enriched in these minerals ${ }^{7}$, including volcanic-hosted massive sulfides (VHMS), porphyry-related metals, and $\mathrm{Au}$ deposits $^{14,16}$. Why these ore deposits are scarce is still an open question. Although many other processes are possible, currently proposed mechanisms include rarity of reduced ore fluids in a relatively oxidized Mesoproterozoic atmosphere $\mathrm{e}^{57}$, or poor preservation because of erosion ${ }^{14,16}$. We speculate that the former is less likely, not only because it is at odds with reported low atmospheric $\mathrm{O}_{2}{ }^{58,59}$ during the Mesoproterozoic Era, but also because of the observed enrichment of these deposits during Nuna assembly when atmospheric $\mathrm{O}_{2}$, at best, was similarly $\mathrm{low}^{57}$. Instead, our observation of relatively less $\mathrm{Nb}, \mathrm{Y}, \mathrm{Zr}$ depleted, arc magmatic samples during RA (Figs. 2, 3) favors enhanced tectonic erosion of active margins, where most of these ore deposits occur or are preferentially preserved ${ }^{14,16}$. Preferential erosion might be considered a limiting preservational bias, but in this case we argue that it reflects tectonic processes specifically associated with RA.

Both pre-collisional and orogenic erosion events might have contributed to the observed dearth in mineral and ore deposits during RA. Pre-collisional erosion during RA may have been more significant than that associated with other supercontinents, because Rodinia accretion is proposed to have been prolonged, and extrovert ${ }^{60}$ via two-sided subduction ${ }^{61,62}$. This tectonic context may have doomed the preservation of VHMS deposits, which requires rapid accretion of continental margins ${ }^{14}$. In addition, many Rodinian orogens (e.g., Grenville, Sveconorwegian, Namaqualand-Natal) exhibit episodic collisions with distension intervals ${ }^{6,63}$, which could facilitate orogenic erosion. Indeed, deep erosion has been observed for the Grenville $^{63,64}$ and the Sveconorwegian orogens ${ }^{65,66}$, which constitute the main collisional suture of Rodinia ${ }^{6}$. Enhanced orogenic erosion is consistent with possible development of large-scale river systems and massive Grenvillian fluvial sediments ${ }^{67,68}$. Removal of the shallow part of the orogens could account for the absence of $\mathrm{Au}$ deposits during RA, which normally occur at $<10 \mathrm{~km}$ depth ${ }^{16}$.

In general, the observed mineral enrichments and depletions during RA (Fig. 1) are an integrated result of mineral crystallization and preservation, instead of purely mineral genesis. The interplay of formation and destruction can also account for the 
temporal distribution of global detrital zircons ${ }^{3}$. During RA, a unique tectonic setting led to non-arc magmatism and enhanced erosion, which in turn resulted in geochemical, mineral, and ore enrichments and depletions that established Rodina as distinct among supercontinental events.

\section{Methods}

Database description and compilation. Compilation of the data, including data query, data filtering, and data resampling, is performed with Pandas 0.21.0 implemented in Python 2.7.11, in which randomness is simulated with Mersenne Twister pseudo-random number generator.

Data on mineral ages, localities, and coordinates are extracted from rruff.info/ ima (as of May 2016), developed at University of Arizona. It is a relational database, with attributes including mineral name, structure, chemical formula, locality name, coordinates, paragenetic mode, and age (if available). Most of the entries are sourced from mindat.org, in which the localities are typically defined on a mine level, distributed at least $5 \mathrm{~km}$ apart. In addition, we have added new entries into the rruff database through brute-force search in scientific publications. In this paper, we queried only high-temperature (high-T, e.g., igneous, metamorphic, and hydrothermal) minerals, of which the ages are well constrained from dating corresponding magmatic, metamorphic, or hydrothermal events, for a total of 108,857 entries.

The high-T mineral entries are further queried by mineral chemistry to investigate occurrences of specific minerals in different geologic time. Queries based on mineral chemistry reveal that the degree of enrichment vary for different species during RA. We compiled the queries of elements to show that $\mathrm{Nb}$ and $\mathrm{Y}$ minerals are enriched, while most others, especially $\mathrm{Se}, \mathrm{Ni}, \mathrm{Co}, \mathrm{Au}$, and PGE elements, are relatively depleted during RA (Fig. 1). Note that we only include elements that make up minerals with at least 20 occurrences during assembly of each supercontinent to be statistically significant.

Geochemical data of igneous rocks are extracted from http://www.earthchem. org/portal (as of April 2017), which is a portal of multiple databases including the Petrological Database (PetDB; http://www.earthchem.org/petdb), North American Volcanic and Intrusive Rock Database (NAVDAT; http://www.navdat.org), the Geochemistry of Rocks of the Oceans and Continents database (GEOROC; http:// georoc.mpch-mainz.gwdg.de/georoc), and the U.S. Geological Survey database (USGS; https://mrdata.usgs.gov/geochem/). It is also a relational database, with attributes including sample ID, rock type, major element concentrations, trace element concentrations, coordinates, ages, etc. We compiled concentrations in igneous samples of $129,161 \mathrm{Zr}$; 105,045 Nb; 121,373 Y; 77,835 Co; and 82,611 Ni whole-rock concentrations, all of which are dated, and associated with reported $\mathrm{SiO}_{2}$ content (wt\%). We also tried to compile concentrations of PGE and $\mathrm{Au}$, but the sample sizes are usually too small $(<5000)$ to be statistically significant. In addition, we included $\sim 50$ data points of $\mathrm{Zr}, \mathrm{Nb}$, and $\mathrm{Y}$ of igneous rocks ${ }^{19}$ missing from EarthChem. The compiled data are further filtered to select only samples of ages between 0 and $3000 \mathrm{Ma}$, with age uncertainties $< \pm 200 \mathrm{Ma}$, and with legitimate geographic (latitudes within $\pm 90^{\circ}$, longitudes within $\pm 180^{\circ}$ ).

Resampling. Bootstrap resampling was performed to minimize spatial and temporal sampling bias $^{21}$. Sample weights were assigned to be inversely dependent on spatiotemporal sample density, according to the relationship

$$
W_{i} \propto 1 / \sum_{j=1}^{n}\left(\frac{1}{1+\left(\left(z_{i}-z_{j}\right) / a\right)^{2}}+\frac{1}{1+\left(\left(t_{i}-t_{j}\right) / b\right)^{2}}\right)
$$

where $n$ is the number of samples in the database, $z$ is spatial location, $t$ is age of the rock, and $a$ and $b$ are normalization coefficients of 1.8 arc degrees $(200 \mathrm{~km})$ and $38 \mathrm{Myr}$, respectively. After calculation of weight $W_{i}$ for each sample $i$ in the database, bootstrap resampling was carried out by random selection of data points based on their weights, i.e., data with larger weights have higher chance to be selected. For each selected data, the synthetic data were drawn from a Gaussian distribution with a mean equal to the original value of the data point and standard deviation equal to the estimated $1 \sigma$ uncertainty of the data point. It is shown that the analysis is insensitive to the resampling size. We built the resampling data set to a size identical to the original database.

Statistical test and tectonic discrimination. The resampled data are plotted with $a \pm 100 \mathrm{Ma}$ bin size at a frequency of $100 \mathrm{Ma}$ (Fig. 2). The apparent enrichments of $\mathrm{Zr}, \mathrm{Nb}$, and $\mathrm{Y}$ concentrations during RA in Fig. 2 are examined as follows. First, trace metal concentrations during the assemblies of Nuna, Rodinia, and Gondwana share similar distribution patterns, ruling out the possibility that Rodinian enrichments are caused by outliers. In addition, two-sample Welch's $t$-tests (Table 1) demonstrate that average $\mathrm{Zr}, \mathrm{Nb}$, and $\mathrm{Y}$ concentrations are generally higher during RA than other supercontinents $(t>0$ and $p<0.05)$. What is more, this enrichment is statistically significant for both mafic $\left(\mathrm{SiO}_{2} 43-51 \mathrm{wt} \%\right)$ and felsic $\left(\mathrm{SiO}_{2} 62-73 \mathrm{wt} \%\right)$ samples in general. The $t$-test is performed with Scipy 0.19.0 implemented in Python 2.7.11.
Tectonic discrimination diagrams (Fig. 3) are plotted based on immobile trace elements $(\mathrm{Zr}, \mathrm{Nb}, \mathrm{Y})$ in igneous rocks ${ }^{25,26}$. Such tectonic discrimination diagrams should be used with caution, especially when the rocks have a small sample size or are of limited spatial and temporal distribution 69,70 Nevertheless, rocks in this study are sampled globally, with age ranges of several hundred million years, and sample sizes of several thousand for each supercontinent assembly. Therefore, the difference observed for immobile trace elements of different supercontinent assemblies suggests unequal tectonic settings.

Data availability. All data analyzed in this study are downloaded from open source databases rruff.info/ima and http://www.earthchem.org/portal. Python codes used to analyze these data are available upon request by e-mailing cliu@carnegiescience.edu.

Received: 20 July 2017 Accepted: 6 November 2017

Published online: 05 December 2017

\section{References}

1. Campbell, I. H. \& Allen, C. M. Formation of supercontinents linked to increases in atmospheric oxygen. Nat. Geosci. 1, 554 (2008).

2. Nance, R. D., Murphy, J. B. \& Santosh, M. The supercontinent cycle: a retrospective essay. Gondwana Res. 25, 4-29 (2014).

3. Cawood, P. A., Hawkesworth, C. \& Dhuime, B. The continental record and the generation of continental crust. Geol. Soc. Am. Bull. 125, 14-32 (2013).

4. Spencer, C. J., Hawkesworth, C., Cawood, P. A. \& Dhuime, B. Not all supercontinents are created equal: Gondwana-Rodinia case study. Geology 41 795-798 (2013)

5. Murphy, J. B. \& Nance, R. D. Do supercontinents introvert or extrovert?: Sm$\mathrm{Nd}$ isotope evidence. Geology 31 873-876 (2003).

6. Bogdanova, S., Pisarevsky, S. \& Li, Z.-X. Assembly and breakup of Rodinia (some results of IGCP Project 440). Stratigr. Geol. Correl. 17, 259 (2009).

7. Cawood, P. A. \& Hawkesworth, C. J. Earth's middle age. Geology 42, 503-506 (2014).

8. Hoffman, P. F., Kaufman, A. J., Halverson, G. P. \& Schrag, D. P. A Neoproterozoic snowball earth. Science 281, 1342-1346 (1998).

9. Knoll, A. H. The multiple origins of complex multicellularity. Annu. Rev. Earth Planet. Sci. 39, 217-239 (2011).

10. Hawkesworth, C., Cawood, P., Kemp, T., Storey, C. \& Dhuime, B. Geochemistry: a matter of preservation. Science 323, 49-50 (2009).

11. Condie, K. C. Episodic continental growth and supercontinents: a mantle avalanche connection? Earth Planet. Sci. Lett. 163, 97-108 (1998).

12. Kemp, A., Hawkesworth, C., Paterson, B. \& Kinny, P. Episodic growth of the Gondwana supercontinent from hafnium and oxygen isotopes in zircon. Nature 439, 580-583 (2006).

13. Ashwal, L. D. The temporality of anorthosites. Can. Mineral. 48, 711-728 (2010).

14. Bierlein, F. P., Groves, D. I. \& Cawood, P. A. Metallogeny of accretionary orogens-the connection between lithospheric processes and metal endowment. Ore Geol. Rev. 36, 282-292 (2009).

15. Bradley, D. C. Secular trends in the geologic record and the supercontinent cycle. Earth Sci. Rev. 108, 16-33 (2011).

16. Goldfarb, R. J., Bradley, D. \& Leach, D. L. Secular variation in economic geology. Econ. Geol. 105, 459-465 (2010).

17. Hazen, R. M. et al. Mercury ( $\mathrm{Hg})$ mineral evolution: a mineralogical record of supercontinent assembly, changing ocean geochemistry, and the emerging terrestrial biosphere. Am. Mineral. 97, 1013-1042 (2012).

18. Dickinson, W. R. Impact of differential zircon fertility of granitoid basement rocks in North America on age populations of detrital zircons and implications for granite petrogenesis. Earth Planet. Sci. Lett. 275, 80-92 (2008).

19. Van Kranendonk, M. J. \& Kirkland, C. L. Orogenic climax of Earth: the 1.2-1.1 Ga Grenvillian superevent. Geology 41, 735-738 (2013).

20. Hazen, R. M. et al. Mineral evolution: episodic metallogenesis, the supercontinent cycle, and the co-evolving geosphere and biosphere. Econ. Geol. 18, 1-15 (2014).

21. Keller, C. B. \& Schoene, B. Statistical geochemistry reveals disruption in secular lithospheric evolution about 2.5 Gyr ago. Nature 485, 490-493 (2012).

22. Peters, S. E. \& Gaines, R. R. Formation of the 'Great Unconformity' as a trigger for the Cambrian explosion. Nature 484, 363-366 (2012).

23. Campbell, I. H. \& Allen, C. M. Formation of supercontinents linked to increases in atmospheric oxygen. Nat. Geosci. 1, 554-558 (2008). 
24. Voice, P. J., Kowalewski, M. \& Eriksson, K. A. Quantifying the timing and rate of crustal evolution: global compilation of radiometrically dated detrital zircon grains. J. Geol. 119, 109-126 (2011).

25. Pearce, J. A., Harris, N. B. \& Tindle, A. G. Trace element discrimination diagrams for the tectonic interpretation of granitic rocks. J. Petrol. 25, 956-983 (1984).

26. Pearce, J. A. \& Norry, M. J. Petrogenetic implications of Ti, Zr, Y, and $\mathrm{Nb}$ variations in volcanic rocks. Contrib. Mineral. Petrol. 69, 33-47 (1979).

27. Evins, P. M. et al. Devil in the detail: the 1150-1000Ma magmatic and structural evolution of the Ngaanyatjarra Rift, west Musgrave Province, Central Australia. Precambr. Res. 183, 572-588 (2010).

28. Iriondo, A. et al. Isotopic, geochemical, and temporal characterization of Proterozoic basement rocks in the Quitovac region, northwestern Sonora, Mexico: implications for the reconstruction of the southwestern margin of Laurentia. Geol. Soc. Am. Bull. 116, 154-170 (2004).

29. Greentree, M. R., Li, Z.-X., Li, X.-H. \& Wu, H. Late Mesoproterozoic to earliest Neoproterozoic basin record of the Sibao orogenesis in western South China and relationship to the assembly of Rodinia. Precambr. Res. 151, 79-100 (2006).

30. McLelland, J. M., Selleck, B. W. \& Bickford, M. Review of the Proterozoic evolution of the Grenville Province, its Adirondack outlier, and the Mesoproterozoic inliers of the Appalachians. Geol. Soc. Am. Mem. 206, 21-49 (2010).

31. Prol-Ledesma, R.-M., Melgarejo, J. C. \& Martin, R. F. The El Muerto "NYF" granitic pegmatite, Oaxaca, Mexico, and its striking enrichment in allanite-(Ce) and monazite-(Ce). Can. Mineral. 50, 1055-1076 (2012).

32. Upton, B., Emeleus, C., Heaman, L., Goodenough, K. \& Finch, A. Magmatism of the mid-Proterozoic Gardar Province, South Greenland: chronology, petrogenesis and geological setting. Lithos 68, 43-65 (2003).

33. Mosher, S., Levine, J. \& Carlson, W. Mesoproterozoic plate tectonics: a collisional model for the Grenville-aged orogenic belt in the Llano uplift, central Texas. Geology 36, 55-58 (2008).

34. Shirey, S. B., Berg, J. H. \& Carlson, R. W. Temporal changes in the sources of flood basalts: isotopic and trace element evidence from the $1100 \mathrm{Ma}$ old Keweenawan Mamainse Point Formation, Ontario, Canada. Geochim. Cosmochim. Acta 58, 4475-4490 (1994)

35. Dijkstra, A. H., Dale, C. W., Oberthür, T., Nowell, G. M. \& Pearson, D. G. Osmium isotope compositions of detrital Os-rich alloys from the Rhine River provide evidence for a global late Mesoproterozoic mantle depletion event. Earth Planet. Sci. Lett. 452, 115-122 (2016).

36. Dhuime, B., Wuestefeld, A. \& Hawkesworth, C. J. Emergence of modern continental crust about 3 billion years ago. Nat. Geosci. 8, 552-555 (2015).

37. Hanson, R. E., Martin, M. W., Bowring, S. A. \& Munyanyiwa, H. U-Pb zircon age for the Umkondo dolerites, eastern Zimbabwe: $1.1 \mathrm{Ga}$ large igneous province in southern Africa-East Antarctica and possible Rodinia correlations. Geology 26, 1143-1146 (1998).

38. Anderson, J. L. \& Morrison, J. Ilmenite, magnetite, and peraluminous Mesoproterozoic anorogenic granites of Laurentia and Baltica. Lithos 80, 45-60 (2005).

39. Vigneresse, J. L. The specific case of the Mid-Proterozoic rapakivi granites and associated suite within the context of the Columbia supercontinent. Precambr. Res. 137, 1-34 (2005)

40. Peck, W. H. \& Valley, J. W. Large crustal input to high $\delta 18 \mathrm{O}$ anorthosite massifs of the southern Grenville Province: new evidence from the Morin Complex, Quebec. Contrib. Mineral. Petrol. 139, 402-417 (2000).

41. Casquet, C. et al. Grenvillian massif-type anorthosites in the Sierras Pampeanas. J. Geol. Soc. Lond. 162, 9-12 (2005).

42. McLelland, J. M. \& Chiarenzelli, J. Isotopic constraints on emplacement age of anorthositic rocks of the Marcy masiff, Adirondack Mts., New York. J. Geol. 98, 19-41 (1990).

43. Grantham, G. H., Eglington, B. M., Thomas, R. J. \& Mendonidis, P. The nature of the Grenville-age charnockitic A-type magmatism from the Natal, Namaqua and Maud Belts of southern Africa and western Dronning Maud Land, Antarctica. Mem. Natl. Inst. Polar Res. 55, 59-86 (2001)

44. Johnson, S. P., Rivers, T. \& De Waele, B. A review of the Mesoproterozoic to early Palaeozoic magmatic and tectonothermal history of south-central Africa: implications for Rodinia and Gondwana. J. Geol. Soc. Lond. 162, 433-450 (2005).

45. Smithies, R. et al. High-temperature granite magmatism, crust-mantle interaction and the Mesoproterozoic intracontinental evolution of the Musgrave Province, Central Australia. J. Petrol. 52, 931-958 (2011).

46. Baadsgaard, H., Chaplin, C. \& Griffin, W. L. Geochronology of the Gloserheia pegmatite, Froland, southern Norway. Nor. Geol. Tidsskr. 64 111-119 (1984)

47. Foord, E., Černý, P., Jackson, L., Sherman, D. M. \& Eby, R. Mineralogical and geochemical evolution of micas from miarolitic pegmatites of the anorogenic Pikes Peak batholith, Colorado. Mineral. Petrol. 55, 1-26 (1995).
48. McCauley, A. \& Bradley, D. C. The global age distribution of granitic pegmatites. Can. Mineral. 52, 183-190 (2014).

49. Kelemen, P., Johnson, K., Kinzler, R. \& Irving, A. High-field-strength element depletions in arc basalts due to mantle-magma interaction. Nature 345, 521 (1990).

50. Woodhead, J., Eggins, S. \& Gamble, J. High field strength and transition element systematics in island arc and back-arc basin basalts: evidence for multiphase melt extraction and a depleted mantle wedge. Earth Planet. Sci. Lett. 114, 491-504 (1993).

51. Aseri, A. A., Linnen, R. L., Che, X. D., Thibault, Y. \& Holtz, F. Effects of fluorine on the solubilities of $\mathrm{Nb}, \mathrm{Ta}, \mathrm{Zr}$ and $\mathrm{Hf}$ minerals in highly fluxed water-saturated haplogranitic melts. Ore Geol. Rev. 64, 736-746 (2015).

52. Gysi, A. P. \& Williams-Jones, A. E. Hydrothermal mobilization of pegmatitehosted REE and $\mathrm{Zr}$ at Strange Lake, Canada: a reaction path model. Geochim. Cosmochim. Acta 122, 324-352 (2013).

53. Keppler, H. Influence of fluorine on the enrichment of high field strength trace elements in granitic rocks. Contrib. Mineral. Petrol. 114, 479-488 (1993).

54. Veksler, I. V., Dorfman, A. M., Kamenetsky, M., Dulski, P. \& Dingwell, D. B. Partitioning of lanthanides and Y between immiscible silicate and fluoride melts, fluorite and cryolite and the origin of the lanthanide tetrad effect in igneous rocks. Geochim. Cosmochim. Acta 69, 2847-2860 (2005).

55. Černý, P., London, D. \& Novák, M. Granitic pegmatites as reflections of their sources. Elements 8, 289-294 (2012).

56. Müller, A. et al. The chemistry of quartz in granitic pegmatites of southern Norway: petrogenetic and economic implications. Econ. Geol. 110, 1737-1757 (2015).

57. Large, R. R. et al. Ocean and atmosphere geochemical proxies derived from trace elements in marine pyrite: implications for ore genesis in sedimentary basins. Econ. Geol. 112, 423-450 (2017).

58. Canfield, D. E. A new model for Proterozoic ocean chemistry. Nature 396, 450-453 (1998)

59. Planavsky, N. J. et al. Low Mid-Proterozoic atmospheric oxygen levels and the delayed rise of animals. Science 346, 635-638 (2014).

60. Evans, D., Li, Z.-X. \& Murphy, J. Four-dimensional context of Earth's supercontinents. Geol. Soc. Lond. Spec. Publ. 424, 1-14 (2016).

61. Cawood, P. A. \& Pisarevsky, S. A. Laurentia-Baltica-Amazonia relations during Rodinia assembly. Precambr. Res. 292, 386-397 (2017).

62. Cawood, P. A., Strachan, R. A., Pisarevsky, S. A., Gladkochub, D. P. \& Murphy, J. B. Linking collisional and accretionary orogens during Rodinia assembly and breakup: implications for models of supercontinent cycles. Earth Planet. Sci. Lett. 449, 118-126 (2016).

63. Rivers, T. Assembly and preservation of lower, mid, and upper orogenic crust in the Grenville Province-implications for the evolution of large hot longduration orogens. Precambr. Res. 167, 237-259 (2008).

64. Hoffman, P. F. \& Grotzinger, J. P. Orographic precipitation, erosional unloading, and tectonic style. Geology 21, 195-198 (1993).

65. Bingen, B., Stein, H. J., Bogaerts, M., Bolle, O. \& Mansfeld, J. Molybdenite ReOs dating constrains gravitational collapse of the Sveconorwegian orogen, SW Scandinavia. Lithos 87, 328-346 (2006).

66. Möller, C., Andersson, J., Dyck, B. \& Lundin, I. A. Exhumation of an eclogite terrane as a hot migmatitic nappe, Sveconorwegian orogen. Lithos 226, 147-168 (2015).

67. Rainbird, R., Cawood, P. \& Gehrels, G. in Tectonics of Sedimentary Basins Recent Advances (eds Busby, C. \& Azor, A.) Ch. 29 (Blackwell Publishing Ltd, UK, 2012).

68. Spencer, C. J., Prave, A. R., Cawood, P. A. \& Roberts, N. M. Detrital zircon geochronology of the Grenville/Llano foreland and basal Sauk Sequence in west Texas, USA. Geol. Soc. Am. Bull. 126, 1117-1128 (2014).

69. Payne, J. L., Ferris, G., Barovich, K. M. \& Hand, M. Pitfalls of classifying ancient magmatic suites with tectonic discrimination diagrams: an example from the Paleoproterozoic Tunkillia Suite, southern Australia. Precambr. Res. 177, 227-240 (2010)

70. Vermeesch, P. Tectonic discrimination diagrams revisited. Geochem. Geophys. Geosyst. 7, Q06017 (2006).

\section{Acknowledgements}

We thank Richard Carlson, Simone Runyon, Shaunna Morrison, and Michael Meyer at the Carnegie Institution for Science for valuable discussions and suggestions. We are grateful to Joshua Golden and Robert Downs at University of Arizona for mineral database building and constructive discussions. Thorough reviews from Peter Cawood and Brendan Murphy contributed greatly to improving this manuscript. This work was supported in part by the NASA Astrobiology Institute, the Deep Carbon Observatory, the Alfred P. Sloan Foundation, the W.M. Keck Foundation, a private foundation, and the Carnegie Institution for Science. 


\section{Author contributions}

The project was designed by C.L., A.H.K. and R.M.H.; Database compilation and statistical analyses was performed by C.L.; C.L., A.H.K. and R.M.H. contributed to the writing of the manuscript.

\section{Additional information}

Supplementary Information accompanies this paper at https://doi.org/10.1038/s41467017-02095-x.

Competing interests: The authors declare no competing financial interests.

Reprints and permission information is available online at http://npg.nature.com/ reprintsandpermissions/

Publisher's note: Springer Nature remains neutral with regard to jurisdictional claims in published maps and institutional affiliations. (c) (i) Open Access This article is licensed under a Creative Commons Attribution 4.0 International License, which permits use, sharing, adaptation, distribution and reproduction in any medium or format, as long as you give appropriate credit to the original author(s) and the source, provide a link to the Creative Commons license, and indicate if changes were made. The images or other third party material in this article are included in the article's Creative Commonslicense, unless indicated otherwise in a credit line to the material. If material is not included in the article'sCreative Commons license and your intended use is not permitted by statutory regulation or exceeds the permitted use, you will need to obtain permission directly from the copyright holder. To view a copy of this license, visit http://creativecommons.org/ licenses/by/4.0/.

(C) The Author(s) 2017 